\title{
UKLJUČENOST DIONIKA U PROCES IZVJEŠTAVANJA O ODRŽIVOSTI
}

\author{
Dubravka Krivačić
}

\author{
Veleučilište u Karlovcu \\ Trg J. J. Strossmayera 9, 47000 Karlovac \\ e-mail: dubravka.krivacic@vuka.hr
}

\begin{abstract}
Sažetak
Usmjerenost poslovnih subjekata održivom razvoju rezultirala je povećanjem potražnje njihovih dionika za objavljivanjem izvještaja o održivosti. Izvještaje o održivosti smatra se odgovornom poslovnom praksom koja eksternim i internim dionicima osigurava potrebne financijske i nefinancijske informacije. Putem izvještaja o održivosti poslovni subjekti dionicima omogućuju sagledavanje njihove učinkovitosti u rješavanju problema održivosti, a ujedno i lakšu procjenu koristi i izazova s kojima se oni u tom procesu susreću. Suvremeni trendovi podrazumijevaju uključivanje dionika u održivo poslovanje sa svrhom postizanja usuglašenosti ciljeva održivosti. Uključenost dionika u poslovne procese postaje jedan od osnovnih mehanizama odgovornosti, sobzirom da očekuje od poslovnih subjekata angažiranje dionika u utvrdivanje, razumijevanje i rješavanje problema održivosti te izvještavanje o odlukama, poduzetim akcijama i ostvarenim učincima. Uključenost dionika, odnosno razvoj odnosa s dionicima, elementi procesa uključivanja dionika, kao $i$ pristupi uključivanja dionika u proces pripreme informacija o održivosti predmet su ovoga rada. Temeljni je cilj rada, kroz pregled dosadašnjih spoznaja o razvoju, koristima i povezanosti izvještavanja o održivosti i uključenosti dionika te kroz analizu procesa uključivanja dionika, ukazati na potrebu primjene sustavnog pristupa uključivanja dionika te potaknuti raspravu i daljnja istraživanja značaja uključivanja dionika u proces izvještavanja o održivosti.
\end{abstract}

Ključne riječi: izvještavanje o održivosti, dionici, uključenost

\section{UVOD}

Tradicionalne modele računovodstvenog izvještavanja poslovnih subjekata, usmjerene većinom na financijske i povijesne podatke, suvremeno poslovno okruženje primorava na transformaciju prema novim oblicima izvještavanja: nefinancijskom izvještavanju (engl. non-financial reporting), odnosno izvještavanju o održivosti (engl. sustainability reporting). Rezultat je to povećanja pritisaka internih i eksternih dionika (engl. stakeholders) na poslovne subjekte da izvještavaju ne samo o financijskim već i učinicima svojeg poslovanja na društvo i okoliš. Izvještavanje o održivosti može se definirati kao „praksa mjerenja, objavljivanja i polaganja računa unutarnjim i vanjskim dionicima u vezi s organizacijskim učinkom, a u cilju održivog razvoja“(GRI, 2006:3). Koristi se kao alat za mijenjanje percepcije eksternih dionika, za poticanje dijaloga s dionicima, odnosno 
važno je u izgradnji komunikacije i odnosa između organizacija i dionika (Bonson i Bednarova, 2015:183).

Dionike se definira kao „pojedince, skupine pojedinaca ili organizacija koji utječu ili na koje utječu aktivnosti, proizvodi ili usluge organizacije i / ili s njima povezana učinkovitost vezana uz pitanja koja treba zajednički rješavati“ (AccountAbility, 2015:5). Od poslovnih subjekata dionici očekuju informacije temeljem kojih ocjenjuju njihovu učinkovitost u svim aspektima društvene odgovornosti, a ujedno donose i vlastite odluke. Svaka skupina dionika zahtijeva informacije koje će im pomoći u odlučivanju ili im osigurati način za ostvarenje prava na informacije o korporativnim aktivnostima i utjecajima na okoliš (Schaltegger i Burritt, 2000:65). Njihovo uključivanje (angažiranje) u poslovne procese, pa tako i proces izvještavanja o održivosti, postaje neophodno. Naime, „uključenost dionika (engl. stakeholder engagement) temeljni je mehanizam odgovornosti, s obzirom da obvezuje organizacije na uključivanje dionika u prepoznavanje, razumijevanje i rješavanje pitanja i problema održivosti, kao i na izvještavanje, objašnjavanje i odgovaranje dionicima za odluke, akcije i ostvarene ishode" (AccountAbility, 2015:5). Razvija se kao sredstvo opisivanja šireg, uključivog i kontinuiranog procesa između poslovnog subjekta i onih na koje potencijalno utječe, a koji obuhvaća mnoštvo aktivnosti i pristupa, odnosno čitav životni ciklus projekta (IFC, 2007:2).

Stoga je temeljni cilj ovoga rada izvođenje zaključaka o ulozi dionika u procesu izvještavanja o održivosti i to kroz pregled dosadašnjih spoznaja o razvoju, koristima i povezanosti izvještavanja o održivosti i uključenosti dionika, kao i kroz analizu procesa uključivanja dionika te važnosti primjene sustavnog pristupa. Radom se ujedno teži poticanju snažnije rasprave o uključivanju dionika u procese izvještavanja, kao i daljnjih istraživanja korisnosti takve poslovne prakse.

\section{IZVJEŠTAVANJE O ODRŽIVOSTI}

Broj poslovnih subjekata koji objavljuju izvještaje o održivosti iz godine u godinu se povećava. Istraživanje KPMG-a ${ }^{1}$ (2017) o korporativnom izvještavanju o odgovornosti (koje je sinonim izvještavanja o održivosti) utvrdilo je tako da je izvještavanje o odgovornosti postalo standardna praksa velikih i srednje velikih poslovnih subjekata te da takvu vrstu izvještaja objavljuje oko tri četvrtine poslovnih subjekata diljem svijeta. Izvještaji o održivosti javni su izvještaji poslovnih subjekata koji internim i eksternim dionicima predočavaju korporativnu poziciju i aktivnosti u vezi s ekonomskom i društvenom dimenzijom, kao i onom o očuvanju okoliša, odnosno nastoje opisati doprinos poslovnih subjekata održivom razvoju (WBCSD, 2002:7). Više je razloga zbog kojih poslovni subjekti objavljuje izvještaje o održivosti. Kroz dosadašnja istraživanja utvrđeno je da poslovni subjekti izvještavaju kako bi odgovorili na očekivanja dionika i doprinijeli dobrobiti društva (Morsing i Shultz, 2006), kako bi upravljali vlastitom legitimnošću (Reverte, 2009), kako bi očuvali ugled (Reynolds i Yuthas, 2008) te kako bi smanjenjem informacijske asimetrije dugoročno ostvarivali profitabilnost (Merkl-Davies i Brennan, 2007, Du i sur., 2010). Izvještavanje o održivosti povećava disciplinu i 
pomaže poslovnom subjektu u promišljanju o dugoročnoj viziji i njezinom definiranju, kao i u podizanju svijesti o praksi održivosti kroz čitavu organizaciju (ACCA, 2013). Ono poboljšava ugled, kontinuirano unaprjeđuje poslovanje, potiče inovacije, svijest o rizicima, poboljšava sustave upravljanja, poboljšava motivaciju zaposlenika, privlači kapital i bolje uvjete financiranja, stvara financijske vrijednosti, zadržava dozvolu za rad te osigurava transparentnost prema dionicima (WBCSD, 2002). Izvještavanje o održivosti stvara vrijednosti temeljem internih promjena, koje se ogledaju u jačanju funkcija poslovnog subjekta, odnosno menadžerskih struktura, odnosa sa zaposlenicima, praćenja performansi te određivanja jasnih ciljeva i strategija, kao i vrijednosti koje se ogledaju u poboljšanju ugleda, dijaloga s dionicima, dokazivanju održivosti poslovanja te omogućavanju usporedivosti organizacija (GRI, 2011). Izvještavanje o održivosti omogućuje promjene unutar organizacije koje rezultiraju uspješnijim procesima te dovode do ušteda i bolje komunikacije s dionicima (Stubbs i Higgins, 2012). Ono doprinosi poboljšanju učinkovitosti poslovnog subjekta i inovacijama, poboljšava ugled poslovnog subjekta, motivaciju zaposlenika te njihovo zapošljavanje i zadržavanje, odnosno poboljšava odnose s dionicima (KPMG, 2013).

O važnosti izvještavanja o održivosti govori i sve veći broj izvještajnih inicijativa, načela i smjernica koje za cilj imaju formiranje odgovarajućeg okvira za izvještavanje (npr. UNGC Principles', OECD Guidelines for Multinational Enterprises', GRI Standards', ISO $\left.26000^{5}, A A 1000 A P^{\circ}\right)$. Međutim, više različitih izvještajnih okvira, kao i složenost procesa izvještavanja, mogu zbuniti poslovne subjekte, osobito one kojima obveza izvještavanja o održivosti nije propisana, odnosno na njihovu odluku o tome što i kako izvještavati. Aktualna je zato rasprava o potrebi harmoniziranja strukture izvještavanja o održivosti na globalnoj razini te su „pohvalna nastojanja Globalne izvještajne inicijative (GRI) za harmoniziranjem izvještajnih oblika, odnosno pokazatelja ostvarenih učinaka“ (WBCSD, 2002:3), i to kroz razvoj Standarda izvještavanja o održivosti. Standardi GRI uređuju objave poslovnih subjekata o njihovim utjecajima na gospodarstvo, okoliš i društvo općenito. Proizašli su iz Smjernica za izvještavanje koje je GRI razvila kako bi se postigao standard trobilančnog izvještavanja o održivosti. Cilj preoblikovanja Smjernica u Standarde prilagodba je nefinancijskog izvještavanja novim zahtjevima korisnika nefinancijskih informacija koji su u stalnom porastu te takav način izvještavanja učiniti standardnom poslovnom praksom. Standardi su strukturirani kao set modularnih standarda koji se sastoji od tri opća i 33 tematski specifična standarda, pri čemu su opći standardi primjenjivi u bilo kojoj organizaciji (serije 100, 200 i 300), dok su tematski standardi specifični (serije 400, 500 i 600) te obuhvaćaju teme ekonomije društva i okoliša (GRI, 2019).

$\mathrm{S}$ istim nastojanjem osnovan je i Međunarodni odbor za integrirano izvještavanje (International Integrated Reporting Committee - IIRC) koji je 2013. objavio Međunarodni okvir za integrirano izvještavanje. Okvir podrazumijeva uključivanje aspekata društva i okoliša u poslovanju poslovnih subjekata u njihove godišnje izvještaje. Njegova je svrha utvrditi načela izvještavanja i elemente sadržaja koji će određivati cjelokupni sadržaj integriranog izvještaja te objasniti temeljne koncepte koji ga podupiru (IIRC, 2013:4). 
Informacije o održivosti poslovni subjekti objavljuju bilo kao samostalne izvještaje ili u okviru već postojećih poslovnih izvještaja. Uključivanje informacija o društvenoj odgovornosti u godišnje financijske izvještaje postaje utemeljen globalni trend koji olakšava ulagačima pristup nefinancijskim informacijama (KPMG, 2015:36). Ipak, s obzirom da je u većini zemalja izvještavanje o održivosti još uvijek dobrovoljno, poslovni subjekti samostalno odlučuju o kojim će informacijama, kada, kako i sukladno kojem okviru, izvještavati. Čak i kada je obvezno, primjerice prema Direktivi 2014/95 Europske unije, koja od poslovnih subjekata zahtijeva da opišu svoj poslovni model, ishode i rizike usvojenih politika vezanih uz obvezne teme, usmjereno je usklađivanju s nekim od poznatih izvještajnih okvira, o odabiru kojeg poslovni subjekti opet samostalno odlučuju (Službeni list EU, L330/1). Očekivano je stoga da pritisci različitih korisnika izvještaja o održivosti utječu na sadržaj izvještaja, kao što se je to bio slučaj i s financijskim izvještavanjem. Izazov tada postaje ostvariti ravnotežu između onoga što je realno za očekivati da će poslovni subjekti objavljivati i onoga što će dionici željeti da bude objavljeno. Naime, „s odgovarajućim strukturama i procesima organizacije mogu poboljšati korporativni ugled i zadobiti povjerenje i lojalnost dionika izvan organizacije: kupaca, vlasnika, dobavljača i drugih o kojima ovise u poslovanju pa su stoga sadržaj, format, plasman, distribucija i objavljivanje eksternih izvještaja važne stavke u izvještajnom okviru organizacije" (Epstein, 2008:227).

Svrha izvještavanja o održivosti stvaranje je veće transparentnosti i odgovornosti te omogućavanje bolje informiranog i snažnijeg odlučivanja u kontekstu u kojem financijski i nefinancijski izazovi postaju međusobno ovisni (Peršić i sur., 2017:300). Očekuje se stoga da izvještaj o održivosti zadovolji određene kriterije, što znači da treba biti fokusiran na potrebe dionika, sadržavati informacije o strateškim odlukama i očekivanim performansama, omogućiti financijske i nefinancijske informacije, biti u digitalnom obliku, biti temeljen na načelima izvještavanja odnosno konceptualnom okviru izvještavanja koji će odražavati integrirano razmišljanje organizacije, biti jednostavan, transparentan, treba ga provjeriti nezavisni procjenitelj te tijekom vremena treba biti ujednačen i standardiziran (Brockett i Rezaee, 2012). Priprema izvještaja koji će zadovoljiti informacijske zahtjeve različitih korisnika nije nimalo lak posao, „s obzirom da je za njegovo provođenje potrebno uvesti određene organizacijske promjene te uložiti vrijeme i resurse u praćenje aspekata poslovanja u vezi s društvom i okolišem, mjerenje učinkovitosti u tim aspektima, analiziranje prikupljenih podataka te sastavljanje izvještaja" (Krivačić, 2017:90). No, praksa je to kojoj se poslovni subjekti moraju prilagoditi jer, sudeći prema rezultatima dosadašnjih istraživanja, izvjesno je da će u narednim godinama pitanja održivosti i dalje zaokupljati pozornost poslovnog svijeta pa će stoga izvještavanje o održivosti postati neizostavnom poslovnom praksom, a harmonizacija pokazatelja učinkovitosti u aspektima odgovornosti poslovnih subjekata prema okolišu i društvenoj zajednici, novim izazovom (Krivačić, 2016). Kvalitetu izvještaja o održivosti dionicima morat će se osigurati, kako bi im objavljene informacije bile pouzdan temelj za odlučivanje (Krivačić, 2017). 


\section{UKLJUČENOST (ANGAŽMAN) DIONIKA}

Odgovornost prema dionicima rezultat je društvene odgovornosti poslovnog subjekta. Kroz dosadašnja istraživanja dano je više definicija dionika pa ih tako Rinaldi i suradnici definiraju kao pojedince ili skupine na koje organizacija utječe ili oni mogu utjecati na njezino poslovanje (2014:86). Bačun i suradnici navode da su dionici organizacije ili pojedinci koji utječu pozitivno ili negativno, ili su pod utjecajem odluka i aktivnosti poduzeća (2012:40). Prema ISO 26000 dionik je pojedinac ili skupina koji imaju interes za neku odluku ili aktivnost organizacije (ISO, 2010:4). Dionici su osobe ili skupine na koje projekt izravno ili neizravno utječe, kao i oni koji mogu imati interes za projekt i / ili mogućnost pozitivnog ili negativnog utjecaja na njegov rezultat (IFC, 2007:10). U širem smislu to su pojedinci ili skupine unutar društva koji su udaljeniji od organizacije (mogu obuhvaćati i buduće generacije i prirodni okoliš), na čija životna iskustva i interese poslovanje, politike i / ili praksa organizacije utječu, dok u užem smislu dionici obuhvaćaju one pojedince ili skupine koji su blizu organizacije, odnosno koji putem odluka koje donose imaju najveću mogućnost utjecaja na uspješnost poslovanja organizacije (Rinaldi i sur., 2014:86). Dionike se može promatrati kao primarne i sekundarne, odnosno interne i eksterne. Primarni su oni koji imaju izravan utjecaj i opipljive interese (to su vlasnici, menadžeri, zaposlenici, kupci, dobavljači i krajnji potrošači) te su presudni za postojanje i uspjeh, odnosno za preživljavanje poduzeća, dok su sekundarni oni koji imaju neizravan utjecaj (konkurenti, javnost, mediji, javna uprava i društvo kao cjelina), ali su i dalje važni za uspjeh poduzeća (Bačun i sur., 2012:40). Interni su dionici pojedinci ili skupine koji sudjeluju u upravljanju poslovnim subjektom (npr. vlasnici, uprava, menadžeri, zaposlenici). Pod izravnim su utjecajem odluka, aktivnosti i rezultata poslovanja poslovnog subjekta, a bez njihovog doprinosa poslovni subjekt ne bi mogao funkcionirati. Eksterni dionici čine poslovnu okolinu poslovnog subjekta na koju poslovni subjekt ima utjecaj, ali i koja ima utjecaj na poslovni subjekt (npr. dobavljači, kupci, vjerovnici, posrednici, konkurenti, društvena zajednica, izvršna vlast). Dionike čine ne samo tradicionalne skupine poput kupaca, zaposlenika i dobavljača, nego i šire interesne skupine kao što su lokalna zajednica, regulatorna tijela, nevladine organizacije, okoliš te buduće generacije (Gray i sur., 2014:162).

Pri detektiranju relevantnih dionika u obzir je potrebno uzeti opseg uključivanja, a sukladno Standardu AA1000SES (AccountAbility, 2015:17) i sljedeće karakteristike dionika: a) ovisnost o poslovnom subjektu (pojedinci ili skupine izravno ili neizravno ovisni o aktivnostima, proizvodima ili uslugama poslovnog subjekta is time povezanim performansama ili oni o kojima je poslovnim subjekt ovisan u svojem poslovanju), b) odgovornost (pojedinci i skupine prema kojima poslovni subjekt ima ili bi u budućnosti mogao imati pravnu, trgovačku, operativnu ili etičku / moralnu odgovornost), c) tenzije (pojedinci ili skupine kojima promptno treba obratiti pozornost $s$ obzirom na financijska, ekonomska, društvena i pitanja okoliša), d) utjecaj (pojedinci i skupine koji imaju utjecaj na strateško i operativno odlučivanje poslovnog subjekta), e) različite perspektive (pojedinci ili skupine čija različita stajališta dovode do drugačijeg razumijevanja situacije i prilika za djelovanje koje inače ne bi bile prepoznate). 
Kako bi povećali transparentnost poslovanja i zadobili povjerenje dionika poslovni subjekti dionicima osiguravaju relevantne informacije o postignutoj razini društvene odgovornosti. Uključivanje dionika u unaprjeđenje društvene odgovornosti poslovnih subjekata stoga nailazi na široku podršku dionika. Naime, „transparentan odnos između poduzeća i njegovih dionika osigurava dugoročno stvaranje povjerenja između svih zainteresiranih strana koje izgrađuju trajniji odnos" (Bačun i sur., 2012:40). U tom procesu utjecaja jedna interesna skupina ne smije imati prioritet pred drugom, odnosno poslovni subjekt njihovim zahtjevima za informacijama treba pristupati s jednakom pažnjom. Važno je stoga pronaći poveznicu sa svakom interesno-utjecajnom skupinom te moguće konflikte preokrenuti u suradnju. Pritom je „odgovornost menadžera prema društvu razmotriti interese svih zainteresiranih strana na koje poslovni subjekt svojim aktivnostima djeluje“ (Branco i Rodrigues, 2007:7). Štoviše, navedeno se nameće kao strateški cilj svakog poslovnog subjekta, čije mu ispunjenje osigurava opstanak na tržištu i daljnji rast. U tom procesu, osim menadžera trebaju sudjelovati i svi drugi zaposlenici. Tako Jensen smatra da je zaposlenicima, kao i menadžerima, potrebno pružiti organizacijsku strukturu koja će im pomoći da se odupru želji za maksimiziranjem kratkoročne financijske učinkovitosti poslovnog subjekta, jer je takvo kratkoročno maksimiziranje profita siguran put u propast (Jensen, 2001). On također smatra da poslovni subjekt ne može maksimizirati dugoročnu tržišnu vrijednost ako ignorira ili pravilno ne tretira važne dionike, jer ne može kreirati vrijednost bez dobrih odnosa s kupcima, zaposlenicima, vjerovnicima, dobavljačima, regulatornim tijelima i zajednicom u cjelini. Donaldson i Preston također ističu da, bez obzira koji je krajnji cilj poslovnog subjekta ili nekog drugog oblika poslovne aktivnosti, menadžeri i poduzetnici moraju u obzir uzeti legitimne interese skupina i pojedinaca koji mogu utjecati na njihove aktivnosti ili na koje se aktivnostima može utjecati (Donaldson i Preston, 1994).

Uključenost dionika rezultat je kontinuiranog razvoja odnosa s dionicima, ostvarene razine komunikacije, kvantitete i kvalitete objavljenih informacija, istraženih i utvrđenih potreba dionika, pruženih prilika za sudjelovanje u poslovnim procesima, odnosno stvaranja pretpostavki za pregovaranje i razvoj partnerskih odnosa s dionicima. Uključivanje dionika ne provodi se odjednom već u fazama, odnosno razvija se kroz generacije (Slika 1). Na početku je ona rezultat određenih pritisaka za ispunjavanjem zahtjeva dionika. Nakon što poslovni subjekti uključivanjem dionika ostvare određene koristi, odnosno riješe određene probleme, dolaze do spoznaje o potrebi njihovog sustavnog i planiranog uključivanja u poslovanje te njihovu uključenost tumače kao preventivni, a ne reaktivni mehanizam. Bolje razumijevanje potreba i interesa dionika rezultira boljim razumijevanjem poslovne okoline, lakšim predviđanjem poslovnih tijekova, a posljedično i većom učinkovitošću. Dionike se integrira u strateške odluke, ali i operativna poboljšanja. Stvaraju se partnerstva i dolazi do ideja za inovacije. Uz pomoć dionika poslovni subjekti dodaju vrijednost svojim poslovnim procesima, ali i stvaraju vrijednost svojim dionicima. Prijelaz iz jedne razvojne faze u drugu odvija se tijekom vremena, odnosno sazrijevanja odnosa poslovnog subjekta i dionika. 


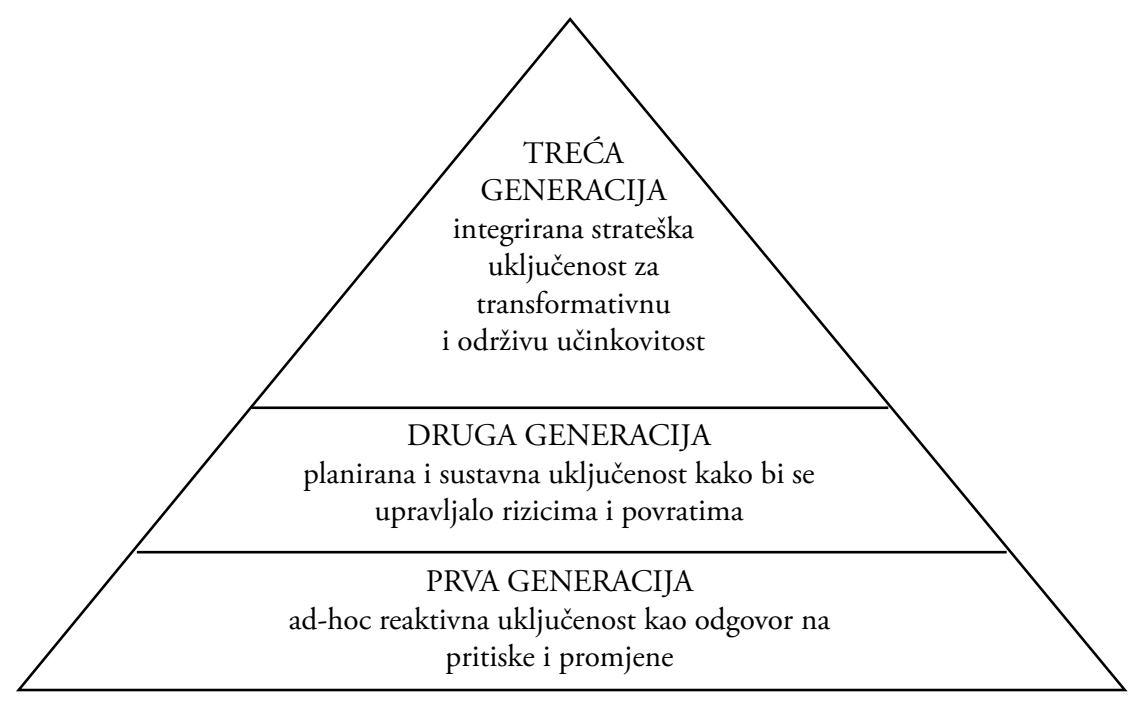

Slika 1. Razvoj uključenosti dionika (AccountAbility, 2015:6)

Uključenost dionika podrazumijeva otvoren i dvosmjeran dijalog između poslovnog subjekta i dionika te razumijevanje i rješenja problema od zajedničkog interesa. Pretpostavka uključivanja dionika spremnost je poslovnog subjekta da ozbiljno razmotri mišljenja i zahtjeve dionika te ih implementira u svoje poslovne procese. Uključivanje dionika pruža priliku za usklađivanjem poslovne prakse s društvenim potrebama, osiguranje poslovne održivosti i ostvarivanje obostranih koristi.

Uključivanje dionika zahtijeva određene resurse (vrijeme tematerijalne, financijske i ljudske resurse). Poslovni subjekti stoga postupno razvijaju komunikaciju s dionicima i uključuju ih u svoje poslovanje. Od praćenja njihovih potreba do suradnje i partnerstva može proći više ili manje vremena, ovisno o sposobnosti i mogućnosti prilagodbe poslovnog subjekta (Slika 2).

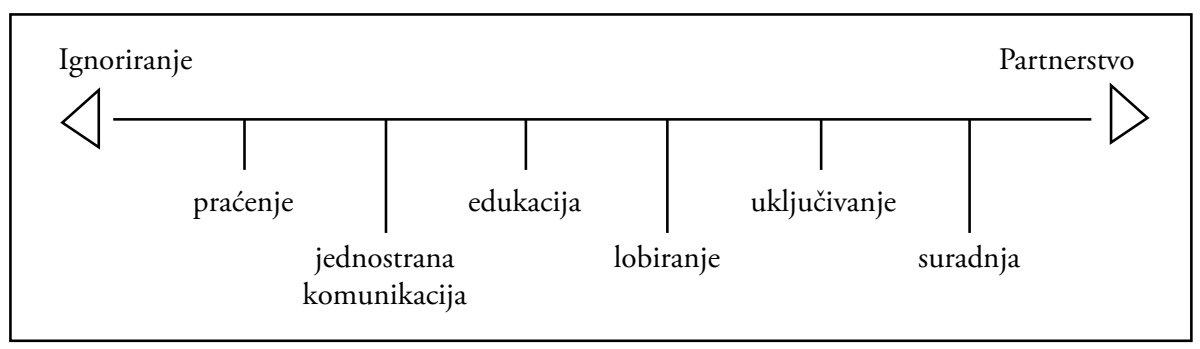

Slika 2. Tijek odnosa s dionicima (Altria Corporate Services, 2004:3)

Potpora dionika poslovnom subjektu je nužna jer bez nje poslovni subjekt nepotrebno ulaže mnogo napora i resursa, a njezin izostanak dovodi do nepovjerenja kod dionika 
i narušavanja ugleda poslovnog subjekta. Za poslovne subjekte važno je stoga ostvariti suradnju i partnerski odnos s dionicima, odnosno uključiti ih u poslovne procese kroz istraživanje njihovih interesa i objavljivanje njima relevantnih informacija.

\section{PROCES UKLJUČIVANJA DIONIKA}

Uključenost dionika proces je koji organizacija koristi za uključivanje relevantnih dionika s jasnom svrhom postizanja usuglašenih ciljeva te se smatra osnovnim mehanizmom odgovornosti s obzirom da obvezuje organizaciju da uključi dionike u utvrđivanje, razumijevanje i odgovaranje na pitanja i probleme održivosti te izvještavanje, objašnjavanje i odgovaranje dionicima za odluke, akcije i učinke (AccountAbility, 2015:5). Prema Međunarodnoj federaciji računovođa (International Federation of Accountants - IFC) (2007) ključne sastavnice uključenosti dionika obuhvaćaju: 1) prepoznavanje i analizu dionika (prepoznavanje ključnih dionika te procjenu njihovih interesa), 2) objavljivanje informacija dionicima (na svrsishodan i pristupačan način te razvijanje komunikacije tijekom čitavog životnog ciklusa projekta), 3) konzultiranje $s$ dionicima (planiranje procesa konzultiranja, konzultiranje svih dionika, dokumentiranje procesa, pružanje povratnih informacija), 4) pregovaranje i partnerstvo (uključivanje spornih i složenih pitanja u proces pregovaranja te formiranje strateških partnerstva), 5) upravljanje žalbama (uspostavljanje pristupačnih i odgovornih sredstva komunikacije kako bi dionici mogli izraziti svoje mišljenje), 6) uključivanje dionika u nadzor projekata (troškova i koristi projekta), izvještavanje dionika o, društvenim i ekonomskim te učincima na okoliš (kako onih konzultiranih, tako i šireg kruga dionika) te 7) razvijanje funkcije menadžmenta (u vezi s upravljanjem procesima uključivanja dionika, praćenje odgovornosti i izvještavanje o napretku).

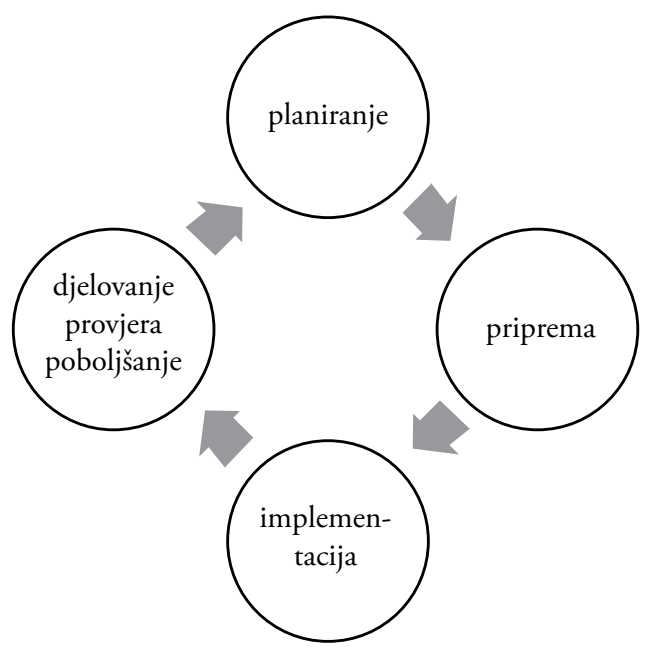

Slika 3. Proces uključivanja dionika (AccountAbility, 2015:19) 
Uključenost dionika omogućuje: pravedniji i održivi društveni razvoj (pružajući priliku onima koji na njega imaju pravo, uzimajući ih u obzir u procesima odlučivanja), lakše utvrđivanje materijalnih stavki za upravljanje održivošću i izvještavanje, bolje upravljanje rizicima i ugledom, udruživanje resursa (znanja, ljudi, novca i tehnologije) u rješavanju problema i postizanju ciljeva koje organizacija sama ne može postići te razumijevanje složene okoline u kojoj organizacija posluje (AccountAbility, 2015:5). Kako bi se postigla svrha uključivanja dionika, potrebno je dizajnirati i implementirati proces uključivanja dionika.

Prema standardu AA1000SES (AccountAbility, 2015: 19) proces uključivanja dionika uključuje četiri faze (Slika 3): 1) planiranje, 2) pripremu, 3) implementaciju te 4) djelovanje, provjeru i poboljšanje. Planiranje obuhvaća profiliranje i mapiranje dionika, utvrđivanje opsega njihove uključenosti, definiranje granica izvještavanja te uspostavu pokazatelja kvalitete uključenosti. Priprema se odnosi na osiguranje potrebnih resursa, određivanje kapaciteta unutar kojih dionike treba uključiti te procjenu rizika uključivanja dionika. Implementacija obuhvaća komunikaciju s dionicima i njihovo uključivanje, opskrbu dionika potrebnim informacijama putem pripremljene dokumentacije na njima razumljivom jeziku, u odgovarajućoj formi i sl., usuglašavanje procedura i pravila uključivanja s dionicima, dokumentiranje uključenosti dionika, po završetku uključivanja dionika razmatranje ostvarenih ciljeva i razvoj akcijskog plana te objavljivanje ishoda uključivanja u roku i na način koji je dogovoren s dionicima. Posljednja faza, koja se odnosi na djelovanje, provjeru i poboljšanje, obuhvaća praćenje i evaluaciju uključivanja dionika, analizu naučenog i planiranje poboljšanja te izvještavanje ostvarenih rezultata uključenosti.

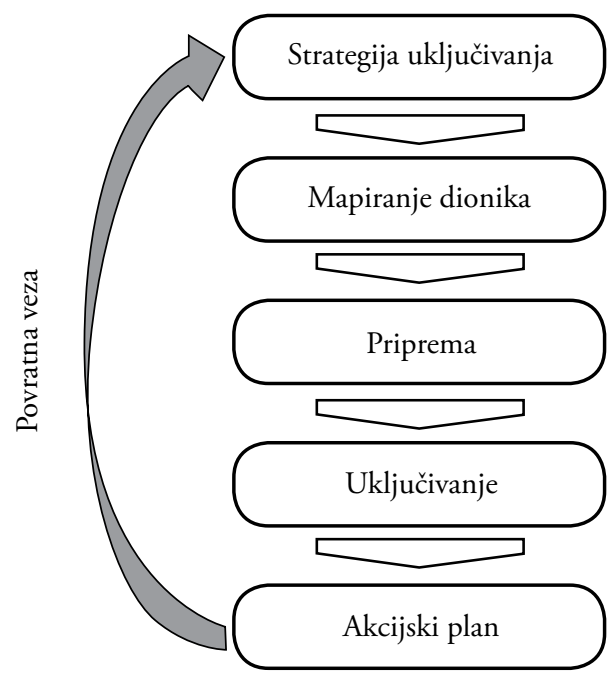

Slika 4. BSR-ov pristup uključivanju dionika (Morris i Baddache, 2012:5) 
Prema BSC-uㄱ (Morris i Baddache, 2012: 5) proces uključivanja dionika sastoji se od pet faza (koraka): 1) donošenje strategije uključivanja, 2) mapiranje dionika, 3) priprema, 4) uključivanje, 5) donošenje akcijskog plana (Slika 4). Prvo je nužno definirati viziju i opseg uključenosti dionika, definirati kriterije za utvrđivanje ključnih dionika te odabrati mehanizme uključivanja. Potom se treba fokusirati na kratkoročne i dugoročne ciljeve koje se želi ostvariti, podršku dionika koju se želi postići te pravila kojih se treba pridržavati. Slijedi uključivanje dionika tako da im se omogući izražavanje zahtjeva i zajedničko rješavanje uočenih problema. Temeljem povratnih informacija od dionika i njihovog mišljenja, revidira se postojeće planove, provjerava ciljeve i osmišljava buduće akcije.

Još jedan od pristupa uključivanja dionika (Slika 5 i Tablica 1) ilustrativno se prikazuje kao odnos utjecaja, odnosno snage dionika i pristupa uključenosti dionika. Odabrani pristup uključivanju dionika ovisi o konkretnom utjecaju i snazi dionika. $\mathrm{Na}$ dnu piramide pristup je u kojemu je komunikacija jednosmjerna i ovisi o odluci samih dionika da pristupe informacijama, koje su im dostupne putem, primjerice web stranice, reklamnih plakata i sl. Potom slijedi faza u kojoj je uključenost dionika i dalje jednosmjerna, ali su informacije ciljane prema određenim skupinama za koje se smatra da bi za informacije mogli biti zainteresirani. Sredina piramide označava početnu razinu uključenosti dionika kod koje poslovni subjekt ispituje zahtjeve dionika, ali dionici nemaju izravan utjecaj na sadržaj izvještaja. Na vrhu piramide pristup je uključivanja dionika koji podrazumijeva sudjelovanje i partnerstvo poslovnog subjekta s dionicima, odnosno njihovu zajedničku odgovornost, odlučivanje, učenje i akcije.

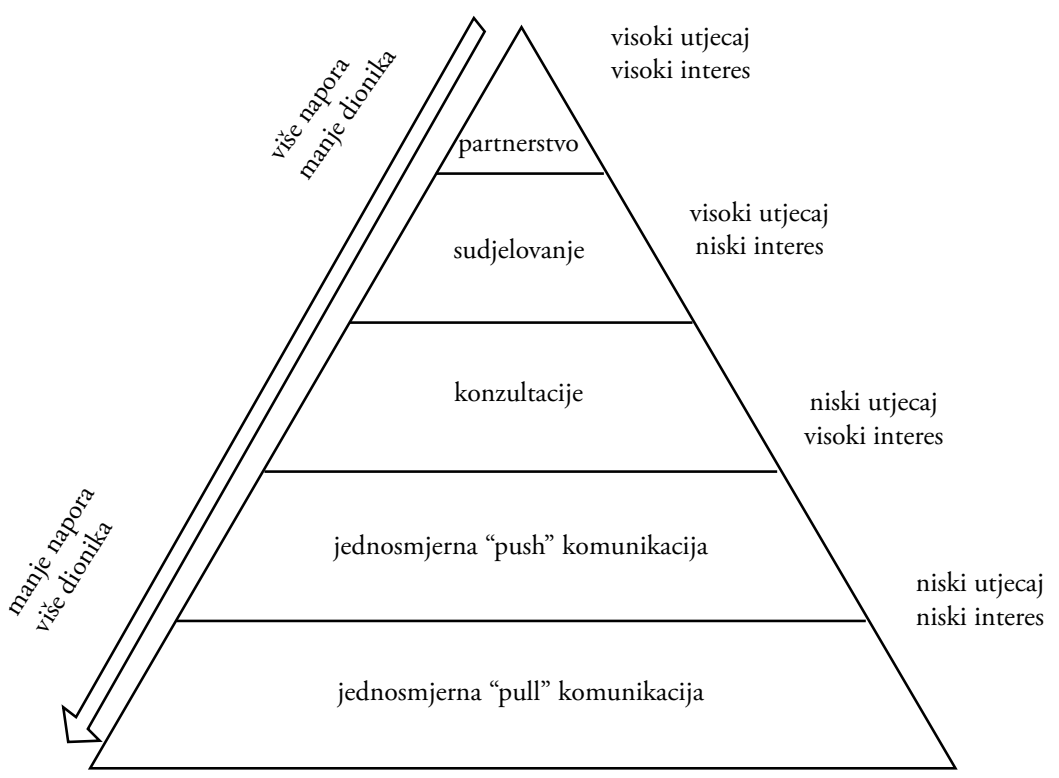

Slika 5. Odnos izmedu utjecaja dionika i pristupa njihove uključenosti (prema Stakeholdermap, 2020) 
Tablica 1. Pristupi uključivanja dionika (prema Stakeholdermap, 2020)

\begin{tabular}{|l|l|}
\hline $\begin{array}{c}\text { Pristup uključivanja } \\
\text { dionika }\end{array}$ & \multicolumn{1}{c|}{ Opis pristupa } \\
\hline Partnerstvo & $\begin{array}{l}\text { Zajednička odgovornost. Dvosmjerna odgovornost, zajedničko učenje, } \\
\text { odlučivanje i akcije. }\end{array}$ \\
\hline Sudjelovanje & $\begin{array}{l}\text { Dio tima, uključenost u obavljanje zadaće ili odgovornost za određeno } \\
\text { područje / aktivnost. Dvosmjerna uključenost unutar granica } \\
\text { odgovornosti. }\end{array}$ \\
\hline Konzultiranje & $\begin{array}{l}\text { Uključivanje, ali ne i odgovornost. Ne znači nužno mogućnost utjecaja } \\
\text { izvan granica konzultiranja. Ograničena dvosmjerna uključenost: } \\
\text { organizacija postavlja pitanja, a dionici odgovaraju. }\end{array}$ \\
\hline „Push“ komunikacija & $\begin{array}{l}\text { Jednosmjerna uključenost. Organizacija emitira informacije svim } \\
\text { dionicima ili cilja na određene skupine dionika koristeći različite } \\
\text { kanale (npr. email, pismenim putem, web, video, letci). }\end{array}$ \\
\hline „Pull“ komunikacija & $\begin{array}{l}\text { Jednosmjerna uključenost. Informacije su dostupne, a dionici odlučuju } \\
\text { hoće li se uključiti (informacije su dostupne npr. na web stranici ili } \\
\text { putem reklamnih plakata). }\end{array}$ \\
\hline
\end{tabular}

No, bez obzira na odabrani pristup strukturiranju procesa uključivanja dionika u poslovne procese i procese pripreme i sastavljanja cilju usmjerenih informacija važno je istaknuti kako je odgovornost prema dionicima temelj sveukupne društvene odgovornosti poslovnog subjekta te je se kao takvu podrazumijeva kod svih vrsta organizacija. Uključivanje dionika u poslovne procese doprinosi njihovom kontinuiranom unaprjeđivanju, ostvarivanju koristi i obostranoj zaštiti interesa. Uključivanje dionika u procese izvještavanja o održivosti od iznimne je važnosti s obzirom da je temeljni cilj izvještavanja pružiti korisnicima izvještaja relevantne i vjerodostojne informacije. Uvažavanje zahtjeva i sugestija dionika u procesima sastavljanja izvještaja doprinosi povećanju vjerodostojnosti izvještaja te zadovoljstva i povjerenja dionika.

Stoga je sastavni dio procesa uključenosti dionika analiza dionika, a uobičajena sje metoda analize dionika matrica dionika (Tablica 2). U matricu se dionike razvrstava ovisno o dvjema varijablama: važnosti i utjecaju. Kvadrant matrice, u tablici označen slovom „A“, predstavlja dionike koji imaju veliki utjecaj na poslovni subjekt i koji su od velike važnosti za njegovo poslovanje. S tim dionicima poslovni subjekt treba uspostaviti kvalitetnu komunikaciju i uključiti njihove interese, zahtjeve i sugestije u procese odlučivanja. Kvadrant označen slovom „B“ predstavlja dionike koji imaju veliku važnost za poslovni subjekt, ali je njihov utjecaj slab. Očekuje se da će ti dionici izražavati određene zahtjeve, iako neće imati utjecaja na to hoće li ih se uključiti u poslovno odlučivanje. Takve dionike treba uzeti u obzir i pokušati zaštititi njihove interese. 
Tablica 2. Matrica dionika (prema Department of Environment, Land, Water and Planning, 2015:120)

\begin{tabular}{|c|c|c|c|c|c|}
\hline & \multicolumn{4}{|c|}{ Važnost dionika } \\
\hline & & $\begin{array}{c}\text { Nepoznata } \\
\text { važnost }\end{array}$ & $\begin{array}{l}\text { Mala važnost ili } \\
\text { je nema }\end{array}$ & $\begin{array}{c}\text { Određena } \\
\text { važnost }\end{array}$ & $\begin{array}{c}\text { Značajna } \\
\text { važnost }\end{array}$ \\
\hline \multirow{4}{*}{ 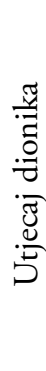 } & $\begin{array}{l}\text { Značajan } \\
\text { utjecaj }\end{array}$ & \multirow{2}{*}{\multicolumn{2}{|c|}{$\mathrm{C}$}} & \multirow{2}{*}{\multicolumn{2}{|c|}{ A }} \\
\hline & $\begin{array}{l}\text { Određeni } \\
\text { utjecaj }\end{array}$ & & & & \\
\hline & $\begin{array}{l}\text { Mali utjecaj ili } \\
\text { ga nema }\end{array}$ & \multirow{2}{*}{\multicolumn{2}{|c|}{$\mathrm{D}$}} & \multirow{2}{*}{\multicolumn{2}{|c|}{ B }} \\
\hline & $\begin{array}{l}\text { Nepoznat } \\
\text { utjecaj }\end{array}$ & & & & \\
\hline
\end{tabular}

Kvadrant označen slovom „C“ predstavlja dionike s velikim utjecajem, čiji se interesi nužno ne preklapaju sa sveukupnim ciljevima poslovnog subjekta. $S$ obzirom da je njihov utjecaj velik i o njemu može ovisiti nesmetano odvijanje poslovanja, potrebno je pronaći zajednička rješenja i pomiriti eventualno suprotstavljene interese. Kvadrant označen slovom „D“ predstavlja dionike koji imaju mali utjecaj na poslovni subjekt pa je i njihova važnost za poslovni subjekt relativno mala. Takve dionike ne treba ignorirati već treba pratiti njihovo ponašanje, interese i stavove. Analizom dionika nastoji se doći do informacija za bolje razumijevanje njihovih interesa te utvrđivanje opsega njihovog uključivanja u poslovne procese.

Nadalje, u procesu uključivanja dionika potrebno je pripremiti neophodne resurse, utvrditi dostatnost postojećih kapaciteta te predvidjeti rizike uključivanja. U fazi implementacije poziva se dionike na uključivanje i komunikaciju pri čemu im je potrebno osigurati potrebne informacije o poslovanju ili projektu u koji se uključuju. Uključenost dionika treba dokumentirati, kao i ostvarene rezultate takve poslovne prakse. $\mathrm{Na}$ temelju utvrđenih rezultata razvija se akcijski plan koji je svojevrstan odgovor na rezultate uključenosti dionika i ispunjavanje njihovih zahtjeva, odnosno uvažavanje njihovih prijedloga. Komunikaciju i uključivanje dionika prati se i ocjenjuje. Ostvareni rezultati postaju podloga za kontinuirano učenje i poboljšanje. Informacije o aktivnostima uključivanja dionika zajedno $s$ ostvarenim rezultatima takvih aktivnosti objavljuje se kroz objavu informacija o društvenoj odgovornosti, odnosno održivosti poslovanja. Informacije trebaju sadržavati obrazloženje načina na koji uključenost dionika doprinosi stvaranju vrijednosti kako za poslovni subjekt tako i za same dionike.

Uključivanje dionika potrebno je stoga strateški osmisliti te sustavno provoditi, kako bi generiralo vrijednosti poslovnim subjektima, ali i samim dionicima. Poslovni subjekti trebaju prihvaćati uključenost dionika kao poslovnu strategiju, ne kao samostalan proces, već kao filozofiju poslovanja (O’Neill, 2018:81). Poslovni subjekti koji prihvate izgrađivati odnose s dionicima imat će više prilika za suradnju, inoviranje i napredovanje 
(O’Neill, 2018:81), a njihov odnos s dionicima dio je ocjene učinkovitosti poslovanja mjerene, primjerice, kroz metodologiju izvještavanja o održivosti (definiranu kroz Standard održivosti GRI, Međunarodni okvir integriranog izvještavanja ili burzovne indekse poput Dow Jones Sustainability Index-a).

\section{ZAKLJUČAK}

Izvještavanje o održivosti rezultat je usmjerenosti poslovnih subjekata održivom razvoju i udovoljavanja potražnji dionika za nefinancijskim informacijama. Kroz izvještaje o održivosti poslovni subjekti prezentiraju svoju odgovornost za okoliš, usmjerenost na zaštitu radnih i ljudskih prava te unaprjeđenje zadovoljstva zaposlenika, uključenost u društvenu zajednicu i podupiranje njezinog razvoja te komunikaciju s dionicima i uključenost njihovih zahtjeva u procese odlučivanja. Kako bi proces izvještavanja osigurao kvalitetu izvještaja i njihovu korisnost dionicima važno je da obuhvati sve značajne aspekte ekonomske i društvene učinkovitosti poslovanja te aspekte učinkovitosti u očuvanju okoliša. Izvještaj treba biti sažet, jasan, pouzdan i usmjeren zadovoljavanju informacijskih potreba ključnih dionika. Očekivanja i interesi dionika polazište su u sastavljanju izvještaja o održivosti. Kroz izvještaje potrebno je uravnotežiti interese i zahtjeve dionika, za koje se zna da će koristiti izvještaje, s potrebama šireg kruga dionika čiji interesi poslovnom subjektu nisu potpuno poznati. Pristup treba biti dovoljno učinkovit kako bi osigurao pravilno shvaćanje informacijskih potreba dionika te što bolju iskoristivost inputa, odnosno potreba dionika. U tom smislu proces uključivanja dionika potrebno je pravilno dokumentirati. Kroz dokumentiranje procesa uključivanja dionika poslovni subjekt objašnjava koji su dionici uključeni, kako i kada ih se uključivalo te kako je njihova uključenost utjecala na sadržaj izvještaja o održivosti. Veća uključenost dionika i njihovih sugestija u izradu izvještaja povećava njihovu vjerodostojnost i pozitivno utječe na njihovu korisnost, kao i na povjerenje dionika prema poslovnom subjektu. Različiti dionici zasigurno će imati svoju ulogu u ostvarivanju zacrtanih ciljeva poslovnog subjekta te ih se treba uključiti u osmišljavanje odgovora na poslovne izazove. Od poslovnih subjekata očekuje se da objavljuju informacije o uključenosti dionika, o tome tko su njihovi dionici, kako ih se uključuje, u vezi s kojim temama te u dijeljenje odgovornosti.

\section{LITERATURA}

AccountAbility (2015). AA1000 Stekeholder Engagement Standard 2015. URL: https:// www.accountability.org/wp-content/uploads/2016/10/AA1000SES_2015.pdf (28.08.2019.)

Altria Corporate Services (2004). Stakeholder engagement planning overview. URL: https://bpgordersettoolkit.rnao.ca/sites/default/files/stakeholder_engagement.pdf (13.05.2020.) 
Association of Chartered Certified Accountants (ACCA) (2013). The business benefits of sustainability reporting in Singapore. ACCA Sustainability Roundtable Dialogue On 24 January 2013. URL: http://www.accaglobal.com/content/dam/acca/global/ PDF-technical/other-PDFs/sustainability-roundtable.pdf (16.05.2019.)

Bačun, D., Matešić, M. i Omazić, M. A. (2012). Leksikon održivog razvoja. Zagreb: Hrvatski poslovni savjet za održivi razvoj.

Bonson, E. i Bednarova, M. (2015). CSR reporting practices of Eurozone companies, Revista de Contabilidad - Spanish Accounting Review, 18(2): 182-193.

Branco, M. C. i Rodrigues, L. L. (2007). Positioning Stakeholder Theory within the Debate on Corporate Social Responsibility. Electronic Journal of Business Ethics and Organisation Studies, 12(1): 5-15.

Brockett, A. M. i Rezaee, Z. (2012). Corporate Sustainability: Integrating Performance and Reporting. Hoboken, NJ: John Wiley \& Sons.

Department of Environment, Land, Water and Planning (2015). Effective Engagement: building relationships with community and other stakeholders - The engagement toolkit (Book 3). Melbourne: State Government of Victoria.

Direktiva 2014/95/EU Europskog parlamenta i Vijeća od 22. listopada 2014. o izmjeni Direktive 2013/34/EU u pogledu objavljivanja nefinancijskih informacija i informacija o raznolikosti određenih velikih poduzeća i grupa, Službeni list Europske unije, L330/1, $57: 1-9$.

Donaldson, T. i Preston, L. E. (1995). The Stakeholder Theory of the Corporation: Concepts, Evidence, and Implications. Academy of Management Review, 20(1): 65-91.

Du, S., Bhattacharya, C. i Sen, S. (2010). Maximizing business returns to corporate social responsibilities: the role of CSR communication. International Journal of Management Reviews, 12(1): 8-19.

Epstein, M. J. (2008). Making Sustainability Work: Best Practices in Managing and Measuring Corporate Social, Environmental and Economic Impacts. Sheffield: Greenleaf Publishing

Global Reporting Initiative (GRI) (2006). Smjernice za izvještavanje o održivosti 3.0. URL: https://www.globalreporting.org/resourcelibrary/GRI-G3-Croatian-Reporting-Guidelines.pdf (21.03.2015.)

Global Reporting Initiative (GRI) (2011). GRI Sustainability reporting: How valuable is the journey? URL: https://www.globalreporting.org/resourcelibrary/StartingPoints-2-G3.1.pdf (09.02.2017.)

Global Reporting Initiative (GRI) (2019). GRI standards. URL: https://www.globalreporting.org/standards (28.06.2019.)

Gray, R., Adams, C. A. i Owen, D. (2014). Accountability, Social Responsibility and Sustainability. Harlow: Pearson Education.

International Finance Corporation (IFC) (2007). Stakeholder Engagement: A Good Practice Handbook for Companies Doing Business in Emerging Markets. Washington: IFC.

International Integrated Reporting Council (IIRC) (2013). The International Integrated Reporting Framework. URL: http://integratedreporting.org/wp-content/ 
uploads/2013/12/13-12-08-THE-INTERNATIONAL-IR-FRAMEWORK-2-1. $\operatorname{pdf}(03.02 .2019$.)

International Organization for Standardization (ISO) (2010). ISO 26000: Guidance on social responsibility. Geneva: ISO.

Jensen, M. C. (2001). Value Maximisation, Stakeholder Theory, and the Corporate Objective Function. European Financial Management, 7(3): 297-317.

Klynveld Peat Marwick Goerdeler (KPMG) (2013). The KPMG Survey of Corporate Responsibility Reporting 2013. URL: https://assets.kpmg/content/dam/kpmg/ $\mathrm{pdf} / 2015 / 08 / \mathrm{kpmg}$-survey-of-corporate-responsibility-reporting-2013.pdf (22.12.2016.)

Klynveld Peat Marwick Goerdeler (KPMG) (2015). Currents of change: The KPMG Survey of Corporate Responsibility Reporting 2015. URL: https://home.kpmg/content/ dam/kpmg/pdf/2015/12/KPMG-survey-of-CR-reporting-2015.pdf (22.12.2016.)

Klynveld Peat Marwick Goerdeler (KPMG) (2017). The road ahead: The KPMG survey of corporate responsibility reporting 2017. URL: https://home.kpmg/content/dam/ $\mathrm{kpmg} / \mathrm{xx} / \mathrm{pdf} / 2017 / 10 / \mathrm{kpmg}$-survey-of-corporate-responsibility-reporting-2017. $\operatorname{pdf}(23.04 .2018$.

Krivačić, D. (2016). Izazovi i koristi izvještavanja o održivosti. Inovacije, tehnologije, edukacija i menadžement. U: Breslauer, N. (ur.), Inovacije, tehnologije, edukacija i menadžement (str. 376-382). Čakovec: Međimursko veleučilište u Čakovcu.

Krivačić, D. (2017). Sustainability Reporting Quality: The Analysis of Companies in Croatia. Journal of Accounting and Management, 7(1): 1-14.

Merkl-Davies, D. i Brennan, N. (2007). Discretionary disclosure strategies in corporate narratives: Incremental information or impression managrment? Journal of Accounting Literature, 26: 116-196.

Morris, J. i Baddache, F. (2012). Back to basics: How to make stakeholder engagement meaningful for your company. Business for Social Responsibility (BSR). URL: https://www.bsr.org/pdfs/events/Back\%20To\%20Basics\%20-\%20How\%20 to $\% 20$ Make\%20SHE\%20Meaningful\%20for\%20your\%20Company(1).pdf (31.07.2016.)

Morsing, M. i Schultz, M. (2006). Corporate Social Responsibility Communication: Stakeholder Information, Response and Involvement Strategies. Business Ethics: A European Review, 15(4): 323-338.

O'Neill, R. (2018). Common threads - Designing impactful engagement. London, New York i San Francisco: SustainAbility. URL: https://sustainability.com/wp-content/ uploads/2018/11/sa-common-threads-full-report.pdf (01.09.2019.)

Peršić, M., Janković, S. i Krivačić, D. (2017). Sustainability Accounting - Upgrading Corporate Social Responsibility. U: Aluchna, M. i Idowu, S. O. (ur.), The Dynamics of Corporate Social Responsibility - A Critical Approach to Theory and Practice (str. 285-303). Cham: Springer.

Reverte, C. (2009). Determinants of Corporate Social Responsibility Disclosure Ratings by Spanish Listed Firms. Journal of Business Ethics, 88(2): 351-366. 
Reynolds, M. i Yuthas, K. (2008). Moral discourse and corporate social responsibility reporting, Journal of Business Ethics, 78(1-2): 47-64.

Rinaldi, L., Unerman, J. i Tilt, C. (2014). The role of stakeholder engagement and dialogue within the sustainability accounting and reporting process. U: Bebbington, J., Unerman, J. i O'Dwyer, B. (ur.), Sustainability accounting and accountability (str. 86-107). New York: Routledge.

Schaltegger, S. i Burrit, R. (2000). Contemporary Environmental Accounting - Issues, Concepts and Practice. Sheffield: Greenleaf Publishing.

Stakeholdermap (2020). Stakeholder Engagement - Definition and Overview. URL: https://www.stakeholdermap.com/stakeholder-engagement.html (13.05.2020.)

Stubbs, W. i Higgins, C. (2012). Sustainability and Integrated Reporting: A Study of the Inhibitors and Enablers of Integrated Reporting. Sydney: Institute of Chartered Accountants in Australia. URL: http://dro.deakin.edu.au/eserv/DU:30064924/ higgins-sustainabilityand-2012.pdf (03.10.2015.)

World Business Council for Sustainable Development (WBCSD) (2002). Sustainable development reporting: Striking the balance. URL: file://CC:/Users/ivana/Downloads/ SustainableDevReporting-StrikingTheBalance.pdf (26.08.2019.) 


\title{
STAKEHOLDER ENGAGEMENT IN THE PROCESS OF SUSTAINABILITY REPORTING
}

\author{
Dubravka Krivačić
}

\begin{abstract}
As businesses move toward sustainability, there is increasing stakeholder demand for sustainability reports. Sustainability reporting is considered to be a responsible business practice that provides external and internal stakeholders with necessary financial and non-financial information. Sustainability reports give business entities an opportunity to provide their stakeholders with an insight into their effectiveness in solving sustainability issues as well as benefits and challenges they face navigating this process. Current trends require stakeholders' involvement in sustainable business practices in order to ensure coordination in achieving sustainability goals. Stakeholder engagement in the business process enhances accountability as it requires businesses to engage stakeholders in the identification, understanding and resolving of sustainability issues, as well as to report on decisions, actions and outcomes. This paper examines stakeholder engagement by analyzing the development of relationship with stakeholders, the elements of stakeholder engagement, as well as the involvement of stakeholders in the process of sustainability reporting. The main objective of our research is to demonstrate the need for a systematic approach to stakeholder engagement and to stimulate discussion and further research on the importance of stakeholder engagement in the process of sustainability reporting. We provide an overview of existing research on the development and benefits of stakeholder engagement in sustainability reporting and analyze this process.
\end{abstract}

Key words: sustainability reporting, stakeholders, stakeholder engagement

\section{AKTEURSBETEILIGUNG AM PROZESS DER NACHHALTIGKEITSBERICHTERSTATTUNG}

\author{
Dubravka Krivačić
}

\section{Zusammenfassung}

Die Ausrichtung von Geschäftssubjekten aufnachhaltige Entwicklung ergab eine vergrößerte Nachfrage der Akteure nach ihren Nachhaltigkeitsberichten. Die Nachhaltigkeitsberichterstattung hält man für ein verantwortungsvolles Wirtschaften, das seinen externen und internen Akteuren die nötigen finanziellen und nichtfinanziellen Informationen sichert. In den Nachhaltigkeitsberichten ermöglichen Geschäftssubjekte den Akteuren, ihre Effizienz beim Lösen des Nachhaltigkeitproblems zu sehen und gleichzeitig leichter den Nutzen und die Herausforderung in diesem Prozess einzuschätzen. Die zeitgenössischen Trends beziehen die Akteursbeteiligung am nachhaltigen Wirtschaften zwecks Erreichung der Nachhaltigkeitsziele ein. Die Akteursbeteiligung an den Geschäftsprozessen wird zu einem der Grundmechanismen der Verantwortung, denn von Geschäftssubjekten wird erwartet, dass Akteure am Feststellen, Verstehen und Lösen der Nachhaltigkeitsprobleme, sowie an der Berichterstattung über Entscheidungen, unternommene Aktivitäten und Leistungen teilnehmen. Die Akteursbeteiligung, bzw. Entwicklung des Verhältisses mit Akteuren, Elemente des Beteiligungsprozesses der Akteure, sowie die Vorgehensweise der Akteursbeteiligung im Prozess der Vorbereitung der Informationen über Nachhaltigkeit sind der Gegenstand dieser Arbeit. Das Grundziel der Arbeit ist, mit Hilfe der Übersicht bisheriger Erkenntnisse über Entwicklung, Nutzen und Verbindung der Nachhaltigkeitsberichterstattung und Akteursbeteiligung, sowie mit Hilfe der Analyse des Prozesses der Akteursbeteiligung auf die Notwendigkeit der Anwendung einer weiteren Anwendung der systematischen Akteursbeteiligung hinzuweisen, sowie weitere Diskussionen und weitere Forschung der Bedeutung der Akteursbeteiligung am Prozess der Nachhaltigkeitsberichterstattung anzuregen.

Schlüsselwörter: Nachhaltigkeitsberichterstattung, Akteure, Beteiligung 